\title{
Effect of Organic Manure and Arbuscular Mycorrhizal Fungi on Growth and Yield of Young Ginger (Zingiber officinale Rosc.)
}

\author{
Samanhudi, Ahmad Yunus, Bambang Pujiasmanto, Muji Rahayu \\ (Department of Agrotechnology, Faculty of Agriculture, Sebelas Maret University)
}

\begin{abstract}
Problems encountered in the development of herbal medicine industry is that most of the raw materials (80\%) came from the forest or natural habitats and the rest (20\%) of the results of traditional cultivation. Provision of raw materials still rely on the natural occurrence of genetic erosion has resulted in some important medicinal plants such as plant ginger, turmeric, kencur, and temulawak. Therefore, this research needs to be done in order to develop the cultivation of medicinal through strengthening technology to increase the production of industrial raw materials and herbal preparations. This research was conducted in the District of Wonogiri, Central Java, Indonesia. The research is focused to improve cultivation techniques of medicinal plants by using various types of organic manure (chicken, goat, and cow) combined with various doses levels of arbuscular mycorrhizal fungi (AMF) application. The purpose of this research is to gain a steady cultivation technology through the use of organic nutrients and arbuscular mycorrhizal fungi so as to increase the production of ginger plants. The results showed that there is no interaction between application of the three types of organic manure (chicken, goat, and cow) with the level of arbuscular mycorrhizal fungi dosage on the growth and yield of the young ginger. Chicken manure, goat manure, and cow manure having the same effect in improving the growth and yield of the young ginger, on the variables of plant height, number of leaves, number of tillers, plant fresh weight, plant dry weight, and the fresh weight of ginger rhizome. Mycorrhizal treatment at various doses $(5,10$, and $15 \mathrm{~g} /$ plant) can increase the plant height, number of leaves, number of tillers, and fresh weight of ginger rhizome, but did not affect the fresh weight and dry weight of plants.
\end{abstract}

Keywords: ginger, Zingiber officinale, organic manure, arbuscular mycorrhizal fungi

\section{Introduction}

Potential of medicinal plants in Central Java is quite large. Center of medicinal plants such as ginger, turmeric, kencur, and temulawak spread in District of Semarang, Sukoharjo, Karanganyar, Purworejo, Boyolali, Banyumas, Magelang, Wonogiri, Rembang, and Jepara. Production in 2006 to reach 13,401 tons of ginger, 10,438 tons of kencur, 13,438 tons of turmeric, and 3,023 tons of temulawak, besides that it still met other products of medicinal plants such as fennel, kapulogo, temukunci, purwoceng, and others.

In the utilization of medicinal plant raw materials are still dependent on plants in natural forests or plantations with traditionally cultivated. Supplying of raw materials or herbal medicine by way of direct collection of natural forests would threaten the existence of the population. Exploitation of wild plants in excess exceeds the regeneration ability of the plant and without cultivation, would interfere with the preservation of the plant (Muharso, 2000). Threats of medicinal plant germplasm conservation of tropical forests is very serious because of the formation of lowland tropical forests over the past two decades suffered severe damage, as a result of timber exploitation, forest encroachment, forest fires, forest conversion, shifting cultivation, etc (Zuhud et al., 2001).

Improvement of medicinal plant cultivation technology to produce high quality of active ingredients can be done by utilizing a variety of organic nutrients and modify the growing environment. The use of organic manure can provide several advantages, such as, (1) can improve fertility of soil physics because it contains elements of $\mathrm{N}, \mathrm{P}, \mathrm{K}, \mathrm{Ca}, \mathrm{Mg}$, and $\mathrm{Cl}$, (2) to increase the activity of soil microorganisms means to increase biological fertility, and (3) in weathering often secrete hormones that stimulate the growth of plants such as auxin, gibberellin and cytokinin. It is certain that fertilization with organic manure on a regular basis will gradually form a nutrient reserve in the soil and to improve the structure and add organic material.

Chicken manure contains more nitrogen than cow, buffalo, horses or goats manure. Nutrient content of chicken manure is relatively higher; this is because the liquid portion (urine) mixed with solid parts in the manure while others do not. The content of $\mathrm{N}$ in liquid form is generally higher than the solid form. The effect of nutrient on the chemical content of the plant is very large because the nutrients in the biosynthesis of secondary metabolites act as precursors (Herbert, 1989). Age of plants has a considerable influence on the chemical content due to the accumulation of secondary metabolites will vary according to the development of a certain age (Sarin, 1982; Tyler et al., 1988).

Utilization of arbuscular mycorrhizal fungi has been shown to play an important role in enhancing the plant nutrient uptake capacity and works to increase plant resistance to drought and pathogens to increase plant 
productivity. Arbuscular mycorrhizal fungi important role in the growth of the plant is its ability to absorb nutrients both macro and micro. Arbuscular mycorrhizal fungi are one type of fungi forming mycorrhizal (symbiotic association between plant roots by fungi). Association between plant roots by these fungi provide excellent benefits for the soil and host plant which is where the fungus grows and multiplies.

Mycorrhiza is one type of fungus that can stabilize soil structure. Physical properties of soil are improved due to the formation of good soil structure such as improved soil porosity, soil permeability improvement and improvement of soil air. Improvement of soil structure will also directly influence the development of plant roots. Besides having mycorrhizal roots can absorb nutrients in the form of bound and are not available to plants. Mycorrhizal external hyphae can absorb phosphate from the soil element and immediately converted into polyphosphate compounds. Polyphosphate compounds then moved into the hyphae and are broken down into organic phosphate that can be absorbed by plant cells. P fertilizer efficiency clearly increased with the use of mycorrhizal (Mosse, 1981).

Organic farming practices also can apply in medicinal plant cultivation. Organic farming is a type of system that involves less intensive use of land by applying cultivation practices which exclude or significantly restrict the use of synthetic chemicals such as pesticides and fertilizers. Organic agriculture focuses on environmental protection and the use of natural resources including the maintenance of soil structure and fertility, water resources and biodiversity (Duruigbo et al., 2013). Organic agriculture is a production system which avoids or excludes the use of synthetic preparation-artificial fertilizers, pesticides, growth accelerators and fodder additives. A technical aspect of organic farming on medicinal plants shows modern concept and environmental friendly. As a staple product in the world, the high demand on organic medicinal plants has increased in last decades. Application of different organic amendments in combinations and in a cumulative manner can supply the nutrient requirement of organic medicinal plants cropping system (Raei and Milani, 2014).

The quality of any organic manure is very difficult to quantify due to differences in the quality of the sources. The results of the study showed that poultry manure was the most impressive on the growth and yield parameters evaluated. This was followed by pig manure and cow dung manure. All the organic manure sources proved better than the control experiment in all the parameters evaluated. This could be attributed to the various nutrient contents of the organic manures (Egbuchua and Enujeke, 2013). Inoculation with an AMF mixture did not only strongly influence shoot, root and rhizome biomass production of ginger but also reduced or even replaced the chemical fertilizer input in the growth stages. This study showed that ginger is a plant with a high mycorrhizal dependency based on shoot biomass production (Santos et al., 2010).

The ginger treated with organic manure performed better in terms of number of leaves, plant height and leaf area. However, there was significant difference between ginger treated with organic manure and those treated with inorganic fertilizer. The result revealed that ginger treated with organic manure performed better than those treated with inorganic fertilizer in terms of number of leaves, plant height and leaf area. Since there was significant difference between ginger treated with organic manure and inorganic fertilizer, it is therefore recommended that ginger farmers should treat ginger with organic manure so as to boost yield (Nmor, 2013).

Inoculation of arbuscular mycorrhizal fungi (AMF) with P. fluorescens in Gerbera helps in effective utilization of superphosphate by changing it into available forms, later taken up by the plants for their better growth and development. On the basis of results, it can be concluded that inoculation of Gerbera with bioinoculants (G. mosseae + A. laevis + P. fluorescens) at lower concentration of superphosphate provides a great future for utilizing the efficient AMF fungi and P. fluorescens for the beneficial effect in the growth establishment and flowering response of Gerbera (Karishma et al., 2013). For growing mycorrhizal plants in hydroponic growth mediums, nutrient elements (especially P) concentration in nutrient solution should be reducing. It seems that any advantage or disadvantage associated with AMF was affected by three factors: kind of plants, kind of AMF and genetic characters of the symbiosis (Shirmohammadi and Aliasgharzad, 2013).

An effort to increase production requires a strategy associated with cultivation techniques, post-harvest processing, conservation, research and development in order to ensure the development and sustainability of production. The strategy must accommodate the interests of economic (production), conservation, and community capacity building. The purpose of this study was to obtain the excellent potential technological packages of medicinal plant cultivation steadily through the utilization of organic nutrients and arbuscular mycorrhizal fungi to increase the growth and yield of ginger plants.

\section{Materials and Methods}

Field experiment was conducted in the District of Wonogiri, Central Java on June to October 2013. Laboratory studies conducted at the Laboratory of Plant Physiology and Biotechnology, Faculty of Agriculture Sebelas Maret University (UNS) Surakarta Indonesia. The plant material used in this study is the ginger rhizomes. Other materials used are paranet, polybag, organic fertilizer (chicken manure, goat manure, and cow manure), and arbuscular mycorrhizal fungi (AMF). Equipment used includes tools for land preparation, 
planting, cultivation, and observations. Research using completely randomized design (CRD) consisting of two treatment factors with 16 treatment combinations and each repeated 3 times. The first factor is the growing medium, made up of four kinds, namely $\mathrm{P} 0=$ soil without organic manure, $\mathrm{P} 1=$ soil + chicken manure, $\mathrm{P} 2=$ soil + goat manure, P3 = soil + cow manure. The second factor is the arbuscular mycorrhizal fungi (AMF), consisting of 4 levels i.e. M0 = without AMF, M1 = 5 g/plant AMF, M2 = 10 g/plant AMF, and M3 = 15 g/plant AMF. Observations were made of the variables of plant height, number of leaves, number of tillers, plant fresh weight, plants dry weight, and the fresh weight of rhizomes. Data were analyzed using analysis of variance (ANOVA) with F-test at 5\% level, and if there is a significant difference followed by Duncan's Multiple Range Test (DMRT) at the 5\% level.

\section{Plant height}

\section{Results and Discussion}

Application of the various types of organic manure can give effect to the increasing plant height of the young ginger (Table 1), as well as the provision of arbuscular mycorrhizal fungi (Table 2). Table 1 show that organic manure can increase the plant height of ginger, compared with no manure treatment. However, the effect of chicken manure, goat manure, and cow manure is not different from one another. In general, organic manure application can respond positively to the growth and yield of the young ginger.

Organic manure can increase the growth and yield of lettuce on observations of plant height, leaf number and fresh weight (Suryanto, 1997). The effect of 15 tons/ha organic manure to the highest plant fresh weight in chicken manure, followed by goat manure, buffalo manure, and cow manure, also reported experiments with tomato plants showed that chicken manure is better than the other manure.

Table 2 also shows that the arbuscular mycorrhizal fungi (AMF) are able to improve the young ginger plant height, compared with non-mycorrhizal treatment. The effect of AMF with a dose of 5 g/plant and 15 $\mathrm{g} /$ plant significantly different compared with a dose of $10 \mathrm{~g} / \mathrm{plant}$ and without AMF treatment. Mycorrhizal utilization can extend and expand the reach of the roots of the nutrient absorption, so it will increase plant nutrient uptake and yield will also increase (Husin and Marlis, 2002).

\section{Number of leaves}

The more the number of leaves are formed, the more the number of leaves that grow so that the place for the process of photosynthesis increases. Based on the results of analysis of variance, the application some kind of organic manure significantly affected the number of leaves. Table 1 shows that chicken manure, goat manure, and cow manure was not significantly different between treatments, but in contrast to untreated manure. Increase the number of leaves on a ginger plant related to effectiveness factor of nutrient absorption by plants. The more the number of leaves, the better the growth, so that the light is absorbed of leaf is more optimal. Results of analysis of variance showed that the AMF doses treatment also significantly affect to the number of leaves. Application of AMF with a dose of $5 \mathrm{~g} / \mathrm{plant}$ and $15 \mathrm{~g} /$ plant significantly different compared without AMF (Table 2).

The much number of leaves will help the process of photosynthesis. The more leaves, the greater of plant leaf area was also greater of sunlight acceptance. The increase in leaf area is basically a plant's ability to cope with shade. Plant growth is affected by the reception of light by leaves. The more light received by the leaves, the more energy to carry out photosynthesis and also increase the photosynthate. Photosynthate is used for growing crops, in this case for the plant height and number of leaves of the young ginger plant.

Table 1. Effect of various types of organic manure on plant height, number of leaves, number of tillers, plant fresh weight, plant dry weight, and rhizomes fresh weight of the young ginger

\begin{tabular}{lllllll}
\hline \hline Organic manure treatment & $\begin{array}{l}\text { Plant } \\
\text { height }(\mathrm{cm})\end{array}$ & $\begin{array}{l}\text { Number } \\
\text { leaves }\end{array}$ & $\begin{array}{l}\text { Number of } \\
\text { tillers }\end{array}$ & $\begin{array}{l}\text { Fresh } \\
\text { weight } \\
\text { plant }(\mathrm{g})\end{array}$ & $\begin{array}{l}\text { Dry weight } \\
\text { of plant }(\mathrm{g})\end{array}$ & $\begin{array}{l}\text { Fresh weight } \\
\text { of } \\
\text { rhizomes } \\
(\mathrm{g})\end{array}$ \\
\hline \hline P0 (without organic manure) & $65.08 \mathrm{a}$ & $26.83 \mathrm{a}$ & $6.87 \mathrm{a}$ & $207.22 \mathrm{a}$ & $14.80 \mathrm{a}$ & $310.50 \mathrm{a}$ \\
P1 (chicken manure) & $81.50 \mathrm{~b}$ & $51.17 \mathrm{~b}$ & $11.54 \mathrm{~b}$ & $274.73 \mathrm{~b}$ & $20.35 \mathrm{~b}$ & $447.26 \mathrm{ab}$ \\
P2 (goat manure) & $85.92 \mathrm{~b}$ & $49.63 \mathrm{~b}$ & $10.79 \mathrm{~b}$ & $258.35 \mathrm{~b}$ & $20.17 \mathrm{~b}$ & $550.74 \mathrm{~b}$ \\
P3 (cow manure) & $90.00 \mathrm{~b}$ & $56.38 \mathrm{~b}$ & $10.88 \mathrm{~b}$ & $297.00 \mathrm{~b}$ & $22.05 \mathrm{~b}$ & $572.13 \mathrm{~b}$ \\
\hline
\end{tabular}

Values followed by the same letter in the same column are not significant different according to DMRT at $5 \%$ level.

\section{Number of tillers}

When organic manure is applied to fertilizer growing medium of ginger plants the amount of nutrients that can be absorbed by ginger plant roots as well as more. Nutrients are then involved in the process of cell division, as well as the substrate and enzyme activator of cell division. The availability of macro and micro nutrients from manure are both going to be able to support better growth, and ultimately also better crops yield. 
A minimum of five percent of the total nutrients absorbed by the plant is used as substrate preparation of organs and tissues (Marschner, 1996).

Crop yield is determined by biomass production during the plant growth and division in the harvested biomass. The biomass production resulting in weight gain can also be followed by the increase in size of plants (Sitompul and Guritno, 1995). This condition is possible if at the time of plant growth, nutrients and other supporting factors available and not be a limiting factor for the growth and division of photosynthesis (photosynthate) to other organs goes well (Gardner et al., 1995). This proved organic manure application can increase the growth and yield of the young ginger in the variable of plant height, number of leaves, number of tillers, and the fresh weight of rhizome.

Table 2 also shows that the AMF doses application is able to increase the tillers number of ginger plant, compared to without mycorrhizal treatment. Application of AMF with a dose of $5 \mathrm{~g} / \mathrm{plant}$ and $15 \mathrm{~g} / \mathrm{plant}$ significantly different compared without AMF.

\section{Plant fresh weight}

Fresh weight of the plants showed levels of water and nutrient uptake by the plant for metabolism. Table 1 shows that chicken manure, goat manure, and cow manure was not significantly different between treatments, but in contrast to untreated manure.

While it can be seen in Table 2 that all treatment doses of AMF results were not significantly different from treatment without application of AMF. Treatment with various types of manure was able to stimulate plant growth. Uptake of higher water and nutrients resulting in crop stover fresh weight also increased. Application doses of AMF did not significantly affect on the fresh weight of crop stover. Allegedly P elements contained in the soil is sufficient for the ginger plant, so that the effectiveness of mycorrhizal less visible.

Table 2. Effect of various doses of arbuscular mycorrhizal fungi (AMF) on plant height, number of leaves, number of tillers, plant fresh weight, plant dry weight, and rhizomes fresh weight of the young

\begin{tabular}{lllllll}
\hline \multicolumn{1}{c}{ ginger } \\
Mycorrhizal doses treatment & $\begin{array}{l}\text { Plant height } \\
(\mathrm{cm})\end{array}$ & $\begin{array}{l}\text { Number of } \\
\text { leaves }\end{array}$ & $\begin{array}{l}\text { Number of } \\
\text { tillers }\end{array}$ & $\begin{array}{l}\text { Fresh } \\
\text { weight } \\
\text { plant }(\mathrm{g})\end{array}$ & $\begin{array}{l}\text { Dry } \\
\text { of }\end{array}$ & $\begin{array}{l}\text { Freight weight of } \\
\text { plant }(\mathrm{g})\end{array}$ \\
rhizomes $(\mathrm{g})$
\end{tabular}

Values followed by the same letter in the same column are not significant different according to DMRT at $5 \%$ level.

\section{Plant dry weight}

That $90 \%$ of the dry weight of the plant is the result of photosynthesis. The process of photosynthesis is inhibited will cause low dry weight of plants (Fitter and Hay, 1981). Table 1 shows that chicken manure, goat manure, and cow manure was not significantly different between treatments, but in contrast to untreated manure. Treatment of various types of organic manure was able to stimulate the growth of the young ginger plant. Uptake of higher water and nutrients resulting in crop stover dry weight also increased. Organic materials may also improve the chemical properties of the soil, which increases the solubility of nutrients in the soil as nutrients $\mathrm{N}, \mathrm{P}$, and $\mathrm{K}$, so that the nutrients needed by plants more available and photosynthesis will increase so that the plant dry weight also increased. While the treatment of various AMF doses did not significantly affect to the stover dry weight of the young ginger plant. High P content in the soil causes the infection of AMF becomes less effective. Improve the plant growth with mycorrhizal depends on the amount of available phosphorus in the soil and types of plants. Strike influenced of mycorrhizal common in phosphorus-deficient soil.

\section{Fresh weight of rhizome}

Table 1 show that organic manure application is able to increase the fresh weight of the young ginger rhizome, especially for goat manure and cow manure. While the effect of chicken manure treatment is not dissimilar to the medium without manure.

Increased growth and yield of ginger in medium with manure may occur due to the availability of some nutrients in the growth medium, and then are expected to be better soil structure and life of microorganisms in the soil more active, resulting in power decaying organic matter into humus faster. With the availability of nutrients such as $\mathrm{N}, \mathrm{P}$, and $\mathrm{K}$, the ginger plant is genetically able to use the entire available supply of nutrients in the medium that will spur the growth of plants and the results shown by the increasing fresh weight of the young ginger rhizome (Table 1). 
Table 2 shows that the application of AMF doses is able to increase the fresh weight of ginger rhizome, compared to without mycorrhizal treatment. Application of AMF with a dose of $5 \mathrm{~g} / \mathrm{plant}, 10 \mathrm{~g} / \mathrm{plant}$, and 15 $\mathrm{g} /$ plant significant different compared without AMF. The availability of $\mathrm{N}, \mathrm{P}$ and $\mathrm{K}$ were higher in medium with organic manure makes this medium is capable of supporting the growth of ginger plants better than the medium that consists only of the soil alone. Nitrogen and phosphorus can be sourced from organic matter (Salampak, 1993) and that the N, P and K elements is an essential macro nutrient required in large amounts by plants in the growth and development.

\section{Conclusion}

Application of organic manure (chicken manure, goat manure, and cow manure) have the same effect to improve the growth and yield of the young ginger on the variables of plant height, number of leaves, number of tillers, plant fresh weight, plant dry weight, and the fresh weight of rhizome. Mycorrhizal treatment at various doses $(5,10$, and $15 \mathrm{~g} /$ plant $)$ can increase the plant height, number of leaves, number of tillers, and fresh weight of ginger rhizome, but did not affect the fresh weight and dry weight of plants. There is no interaction between the treatment of the three types of organic manure (chicken, goat, and cow manure) with doses of arbuscular mycorrhizal fungi (AMF) on growth and yield of the young ginger plant.

\section{Acknowledgements}

The authors are grateful to the Ministry of Research and Technology Republic of Indonesia for fully funding of this research through Insentif Riset Sistem Inovasi Nasional (Insentif Riset SINas) Program FY 2013. We would like to thank the PT Deltomed Laboratories, Wonogiri-Indonesia for good cooperation of the advice and help at running this experiment.

\section{References}

[1]. Duruigbo C.I., Okereke-Ejiogu, E.N., Nwokeji, E.M., Peter-Onoh, C.A., Ogwudire, V.E. and Onoh, P.A. 2013. Integrated remediation strategies for sustaining agrobiodiversity degradation in Africa. IOSR Journal of Agriculture and Veterinary Science (IOSR-JAVS). 3(4): 16-23.

[2]. Egbuchua, C.N. and Enujeke, E.C. 2013. Growth and yield responses of ginger (Zingiber officinale) to three sources of organic manures in a typical rainforest zone, Nigeria. J. Hortic. For. 5(7): 109-114.

[3]. Fitter, A.H. and Hay, R.K.M. 1981. Fisiologi lingkungan tanaman. Gadjah Mada University Press. Yogyakarta.

[4]. Gardner, F.P., Pearce, R.B., dan Mitchel, R.L. 1995. Fisiologi tanaman budidaya. (terjemahan). UI Press. Jakarta.

[5]. Herbert, R.B. 1989. The Biosynthesis of Secondary Metabolities. $2^{\text {nd }}$ ed. Chapman and Hal. New York.

[6]. Husin, E.F. dan Marlis, R. 2002. Aplikasi cendawan mikoriza arbuskular sebagai pupuk biologi pada pembibitan kelapa sawit, Prosiding Seminar Nasional BKS PTN Wilayah Indonesia Barat. FP USU Medan.

[7]. Karishma, Yadav, K., Tanwar, A. and Aggarwal, A. 2013. Impact of arbuscular mycorrhizal fungi and Pseudomonas fluorescens with various levels of superphosphate on growth enhancement and flowering response of Gerbera. Journal of Ornamental Plants (Journal of Ornamental and Horticultural Plants), 3(3): 161-170.

[8]. Marschner, H. 1996. Mineral nutriton of higher plants. Academic Press. London-Tokyo-Toronto.

[9]. Mosse, B. 1981. Vesicular-arbuscular mycorrhiza research for tropical agriculture. Research Bulletin. Hawaii Institute of Tropical Agriculture and Human Resources. College of Tropical Agriculture and Human Resources. University of Hawaii. $82 \mathrm{p}$.

[10]. Muharso. 2000. Kebijakan pemanfaatan tumbuhan obat Indonesia. Makalah Seminar Tumbuhan Obat di Indonesia, Kerjasama Inonesian Research Centre For Indegeneous Knowledge (INRIK), Universitas Pajajaran dan Yayasan Ciungwanara dengan Yayasan KEHATI 26-27 April 2000.

[11]. Nmor E.I. 2013. Response of ginger (Zinibar officinale) to organic and inorganic fertilizer in rain forest zone. J. of Agriculture and Veterinary Sciences, 5(2): 133-139.

[12]. Raei, Y. and Milani, M.A. 2014. Organic cultivation of medicinal plants: a review. J. Bio. \& Env. Sci. 4(4): 6-18.

[13]. Salampak. 1993. Studi asam fenol tanah gambut pedalaman dari bereng bengkel pada keadaan anerob. Tesis. Program Pascasarjana IPB. Bogor.

[14]. Santos, R.d., Girardi, C.G., Pescador, R., Stürmer, S.L. 2010. Effects of arbuscular mycorrhizal fungi and phosphorus fertilization on post vitro growth of micropropagated Zingiber officinale Roscoe. Revista Brasileira de Ciência do Solo, 34(3): 765-771.

[15]. Sarin, Y.K. 1982. Indian row materials for the production of tropane alkaloids. In: Atal, C.K. and Kapur, B.M. (Eds). Cultivation and Utilization of Medicinal Plants. Regional Research Laboratory Jammu-Tawi. New Delhi. India.

[16]. Shirmohammadi, E. and Aliasgharzad, N. 2013. Influence of Glomus etunicatum and Glomus intraradices fungi inoculums and micronutrients deficiency on root colonization and dry weights of tomato and sorghum in perlite bed culture. Afr. J. Biotechnol. 12(25): 3957-3962.

[17]. Sitompul, S.M. and Guritno, B. 1995. Analisis pertumbuhan tanaman. Gadjah Mada University Press. Yogyakarta.

[18]. Suryanto, 1997. Bahan organik untuk budidaya hortikultura. Makalah Seminar Ilmiah Nasional Pengembangan Hortikultura. Fakultas Pertanian UGM. Yogyakarta. 25 September 1997.

[19]. Tyler, V.E., Brady, L.R., and Robbers, J.E. 1988. Pharmacognosy. Lee \& Febiger. Philadelphia. 519 p.

[20]. Zuhud, E.A.M., Azis, S., Ghulamahdi, M., Andarwulan, N., dan Darusman, L.K. 2001. Dukungan teknologi pengembangan obat asli Indonesia dari segi budaya, pelestarian, pasca panen. Lokakarya Agribisnis Berbasis Biofarmaka, Pemanfaatan dan Pelestraian Sumber Hayati Mendukung Agribisnis Tanaman Obat. 